\title{
Comparison of Substrates for Measuring Serum Choline Esterase Activity in Hepato-Biliary Disease
}

\author{
By Tetsuo Uete, Kumiko Masui and Machiko Miyauchi \\ Department of Clinical Investigation, Kitano Hospital, Tazuke Kofukai Medical Research Institute, kita-ku, \\ Osaka City, Japan
}

(Received January 21/April 30, 1985))

Summary: The efficacy of various substrates for measuring serum choline esterase for the evaluation of hepatic function was studied using o-toluoyl- and succinyl-choline, and acetyl, butyryl- and propionylthiocholine. In hepatic disease, the serum choline esterase activity with these substrates was decreased at a similar rate, showing no significant difference. In $78-84 \%$ of cases with hepatic cirrhosis the enzyme activity with these substrates was less than $50 \%$ of the average level of normal individuals, but in acute and chronic hepatitis only $4-9$ and $12-14 \%$ of patients showed these lower values, respectively. The present study indicates the usefulness of sequential monitoring of serum choline esterase activity with any of these substrates for assessing hepatic disease, particularly cirrhosis, and for monitoring the course of hepatic disease.

\section{Vergleich von Substraten zur Messung von Cholinesterase im Serum bei hepato-biliären Erkrankungen}

Zusammenfassung: o-Toluoyl- und Succinylcholin sowie Acetyl-, Butyryl- und Propionylthiocholin wurden hinsichtlich ihrer Wirksamkeit als Substrat für die Bestimmung von Cholinesterase zur Bewertung der Leberfunktion untersucht. Bei Lebererkrankungen war die mit diesen Substraten gemessene katalytische Konzentration von Cholinesterase im Serum in gleichem Maße verringert, es gab keine signifikanten Unterschiede. Bei 78-84\% der Fälle von Lebercirrhose betrug die mit diesen Substraten gemessene katalytische Konzentration weniger als $50 \%$ des Referenzwertes Gesunder; bei akuter und chronischer Hepatitis jedoch zeigten nur 4-9\% bzw. 12-14\% der Patienten diese niedrigen Werte. Die vorgelegte Untersuchung zeigt den Nutzen der Bestimmung der katalytischen Aktivität von Cholinesterase mit jedem der Substrate für die Feststellung von Lebererkrankungen, besonders Cirrhose, und für deren Verlaufskontrolle.

\section{Introduction}

The determination of plasma choline esterase (EC 3.1:1.8) activity is çinically useful for evaluating certain pathological conditions:

First, its low activity could be the consequence of reduced protein synthesis due to pathological cause such as liver cirrhosis, cancer, or malnutrition;

second, there may be enzyme inhibition, indicative of organophosphate poisoning; or

third, low activity could indicate a genetic variant in a perfectly healthy subject $(1-3)$.
In addition, in the surgical treatment of cirrhotic patients with portocaval or lienorenal anastomosis, assays of serum choline esterase and albumin are very important for evaluating the prognosis of patients before operation and during the follow up period (4). Serum choline esterase assay has also proved helpful in assessing the progress of liver transplant cases (5).

Succinylcholine has been recommended for the identification of the atypical variant of serum choline esterase (6-9). Propionylthiocholine has also been recommended as a more useful substrate than benzoylcholine, acetyl- or butyryl-thiocholine $(10-12)$, 
although there is controversy (13). In addition, assay at $37^{\circ} \mathrm{C}$ is considered to be better than at lower temperature such as $25^{\circ} \mathrm{C}(2)$.

On the other hand, for assessing hepatic function no significant difference among acetyl-, butyryl- and propionyl-thiocholine was demonstrated by studying choline esterase activity at $25^{\circ} \mathrm{C}(14)$. At present, no comparative study is available with respect to assay temperature for the evaluation of hepatic function. Recently, o-toluoylcholine was reported to be a more specific substrate for the assay of serum pseudocholine esterase (15), but its clinical significance is not known. Although succinylcholine is presumed to be the most useful substrate for detecting the atypical variant of serum pseudocholine esterase (6), its efficacy for assessing hepatic function is also not known.

To obtain further information concerning the efficacy of $o$-toluoylcholine and succinylcholine for measuring serum choline esterase activity in the assessment of hepatic function, enzyme activities with these substrates were studied in various sera at $25^{\circ} \mathrm{C}$ and $37^{\circ} \mathrm{C}$, and compared with the activities obtained with acetyl-, butyryl- and propionyl-thiocholine.

\section{Materials and Methods}

\section{Materials}

$o$-Toluoylcholine and succinylcholine chloride were purchased from Kyowa Hakko Kyogyo Co., and Tokyo Kasei Chem. Co., respectively. Choline oxidase, peroxidase, phenol and 4aminoantipyrine $(6,15)$ were obtained from Kyowa Hakko Kyogyo Co. Acetyl-, butyryl-, and propionyl-thiocholine iodide, 2,2'-dithiodipyridine (16) and the other regents used were purchased from Nakarai Chem. Co., Japan.

\section{Methods}

Patients with hepatic disease at various stages visited our clinic from January to December, 1979, and were studied at random with respect to serum choline esterase activity. The diagnosis of 179 patients with hepatic disease was made by clinical, biochemical and histological examination, and by computed tomography, scintigraphy and ultrasound sonication. Of these, 140 patients satisfied predicted criteria for chronic non-active and active liver disease $(17-21)$, and also revealed these disorders by morphological evaluation $(22-24)$.

The activity of serum choline esterase was measured by the rate assay method previously described, using acetyl-, butyryl-, or propionyl-thiocholine at a concentration $12.5 \mathrm{mmol} / \mathrm{l}$ at $37^{\circ} \mathrm{C}$. $2,2^{\prime}$-Dithiodipyridine was used as the chromogenic reagent for estimating thiocholine liberated from the substrate (16). The activity was also determined with $o$-toluoylcholine, $0.5 \mathrm{mmol} / 1$, and succinylcholine, $0.5 \mathrm{mmol} / 1$, by estimating choline liberated from these substrates using choline oxidase and a coupled enzyme system at $37^{\circ} \mathrm{C}(6,15)$.

\section{Results}

Effect of substrate concentration on choline esterase activity in serum of normal subjects and in patients with hepatic cirrhosis; $K_{\mathrm{m}}$ values for various substrates

With increasing substrate concentrations of acetyl-, butyryl-, and propionyl-thiocholine, the measured choline esterase activity in serum increased, reaching a plateau at 4 to $9 \mathrm{mmol} / 1$ in normal serum and 2.5 to $3 \mathrm{mmol} / \mathrm{l}$ in cirrhotic serum. With $o$-toluoyl-choline, activity became maximal at about $0.4 \mathrm{mmol} / \mathrm{l}$ in both groups. The $K_{\mathrm{m}}$ of serum choline esterase was studied on 5 normal individuals and 5 patients with hepatic cirrhosis. The average values of the $K_{\mathrm{m}}$ of this enzyme in normal serum for acetyl-, butyryl-, and propionylthiocholine and $o$-toluoylcholine were $0.1,0.098$, 0.076 and $0.39 \mathrm{mmol} / \mathrm{l}$, respectively, under the conditions of this study. The corresponding values for serum from patients with hepatic cirrhosis were 0.102 , $0.093,0.070$ and $0.035 \mathrm{mmol} / 1$, respectively, showing no significant difference from those of normal individuals (figs. 1 and 2).

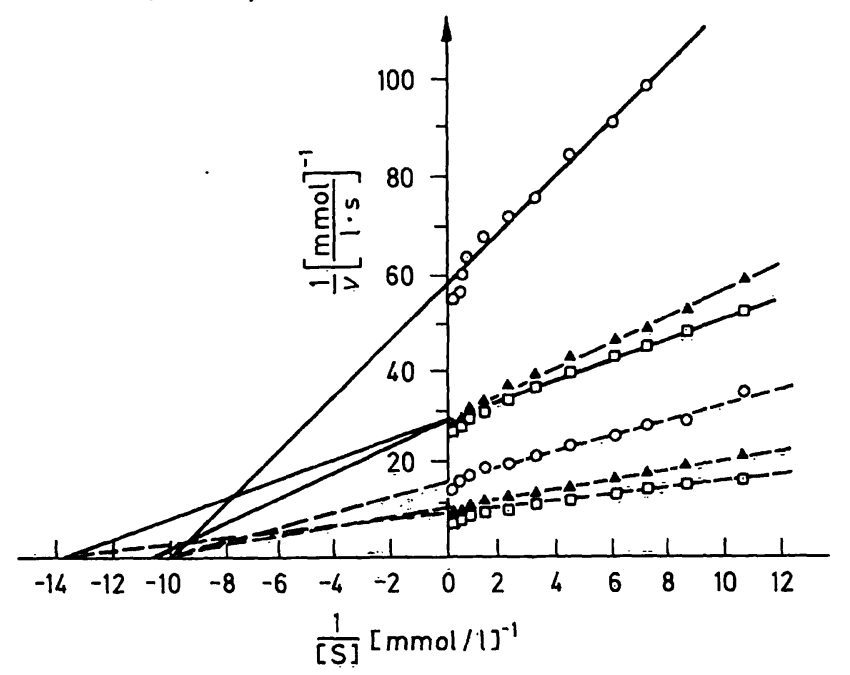

Fig. 1. Lineweaver-Burk plots for serum choline esterase in normal subjects and in patients with hepatic cirrhosis. The average values of 5 experiments carried out using sera from normal subjects and hepatic cirrhosis patients are presented.

Normal subjects - - and hepatic cirrhosis with acetylthiocholine $\odot$, butyrylthiocholine $\Delta$ and propionylthiocholine $\square$.

\section{Effect of temperature and incubation time on serum choline esterase assay}

Increasing the assay temperature from 25 to $37^{\circ} \mathrm{C}$ enhanced the enzyme activity. Performance of the assay with propionylthiocholine at $37^{\circ} \mathrm{C}$ for a longer incubation time than 7 to 8 min did not give accurate results under the conditions of this method, owing to non-linearity between enzyme activity and incubation time (fig. 3). However, shorter incubation times, e. g. 5 min, resulted in accurate determinations. 


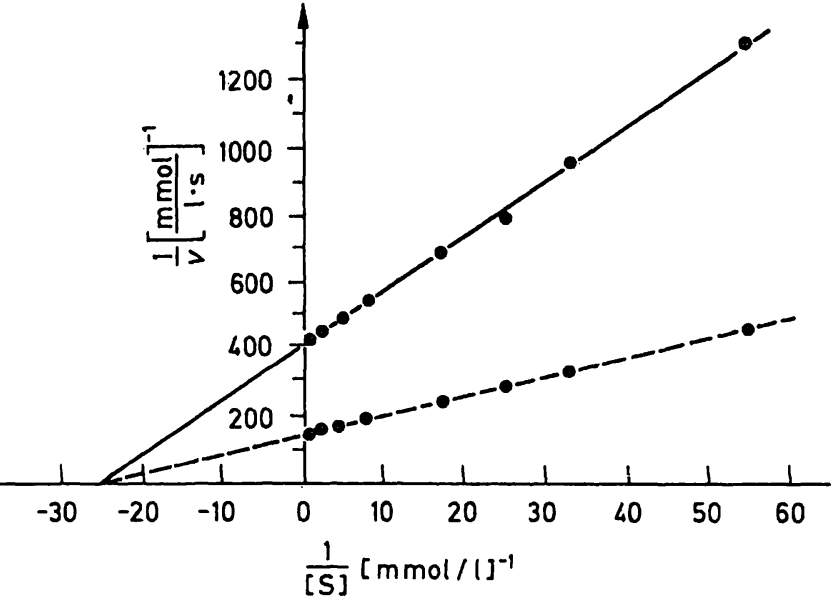

Fig. 2. Lineweaver-Burk plots for serum choline esterase in normal subjects and in patients with hepatic cirrhosis, using $o$-toluoylcholine as substrate. The average values of 5 experiments carried out using sera from normal subjects and hepatic cirrhosis patients are presented. Normal subjects - - - hepatic cirrhosis -

Using acetyl-, butyryl-, propionyl-thiocholine or $o$ toluoylcholine, serum choline esterase activity in patients with hepatic cirrhosis measured at 25 or $37^{\circ} \mathrm{C}$ was significantly decreased compared with that in normal individuals $(\mathrm{p}<0.01, \mathrm{tab} .1)$. The average serum enzyme levels in patients with hepatic cirrhosis, measured with $o$-toluoylcholine at 25,30 , and $37^{\circ} \mathrm{C}$ were about 29,31 and $31 \%$ of the average levels of normal serum, respectively (tab. 1). Similarly, with acetylthiocholine as substrate, the corresponding values were 31,33 , and $32 \%$ of the respective average levels of normal serum (tab. 1). Similar results were also obtained with butyryl- and propionyl-thiocholine (tab. 1). These ratios of the activity at various assay temperature did not change with the incubation time.

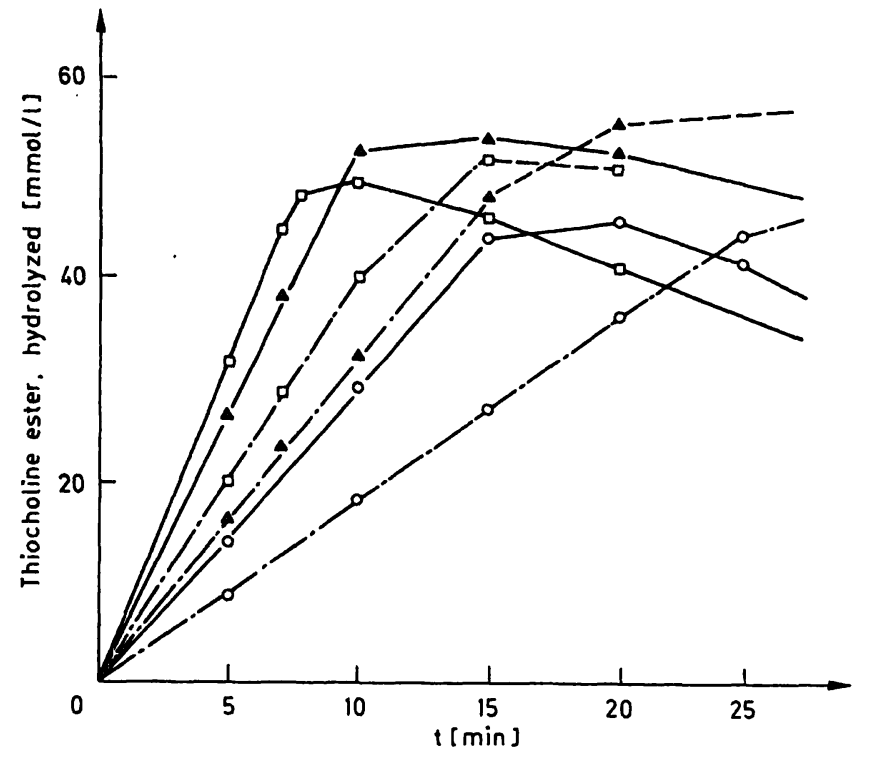

Fig. 3. Effect of temperature and incubation time on serum choline esterase activity.

With acetylthiocholine $\mathrm{o}$, butyrylthiocholine $\boldsymbol{\Delta}$, and propionylthiocholine $\square$ at $37^{\circ} \mathrm{C}-$ and $25^{\circ} \mathrm{C}-\cdot-\cdot-$

With a short period of incubation, e. g. $5 \mathrm{~min}$, the difference in serum enzyme activity between normal subjects and patients with hepatic cirrhosis was greater at $37^{\circ} \mathrm{C}$ than at $25^{\circ} \mathrm{C}$ (tab. 1). However, at a lower temperature such as $25^{\circ} \mathrm{C}$, and with a longer period of incubation, e. g. $10 \mathrm{~min}$, a better separation of enzyme activity in serum of normal subjects and in patients with hepatic cirrhosis was obtained, showing no significant difference compared with the results assayed at $37^{\circ} \mathrm{C}$ with a short period of incubation.

Tab. 1. Effect of temperature on serum choline esterase activity with various substrates.

Figures in parentheses are activity fraction referred to the corresponding normal values

Enzyme catalytic activity concentration, substrate hydrolysed $[\mu \mathrm{mol} / \mathrm{s} \cdot 1](\overline{\mathrm{x}} \pm \mathrm{SD})$

No: of $o$-Toluoylcholine

Acetylthiocholine

Butyrylthiocholine

Propionylthiocholine cases

\begin{tabular}{lclcrrr}
\hline Normal subjects & & & & & \\
$25^{\circ} \mathrm{C}$ & 15 & $3.82 \pm 0.83$ & $34.0 \pm 7.3$ & $63.5 \pm 16.2$ & $66.0 \pm 17.3$ \\
$30^{\circ} \mathrm{C}$ & 15 & $4.68 \pm 0.82$ & $44.0 \pm 5.3$ & $79.7 \pm 13.0$ & $82.7 \pm 13.7$ \\
$37^{\circ} \mathrm{C}$ & 15 & $5.82 \pm 0.97$ & $58.0 \pm 8.3$ & $102.8 \pm 14.5$ & $106.5 \pm \pm 14.0$ \\
$37^{\circ} \mathrm{C} / 25^{\circ} \mathrm{C}$ & & $1.59 \pm 0.05$ & $1.73 \pm 0.41$ & $1.69 \pm 0.41$ & $1.64 \pm 0.40$ \\
& & & & & \\
Hepatic cirrhosis & & & & & & \\
$25^{\circ} \mathrm{C}$ & 15 & $1.12 \pm 0.50(0.29)$ & $1.0 .7 \pm 4.8(0.31)$ & $20.8 \pm 10.5(0.32)$ & $21.3 \pm 11.0(0.32)$ \\
$30^{\circ} \mathrm{C}$ & 15 & $1.45 \pm 0.65(0.31)$ & $14.7 \pm 5.2(0.33)$ & $25.2 \pm 10.2(0.32)$ & $26.5 \pm \pm 10.7(0.32)$ \\
$37^{\circ} \mathrm{C}$ & 15 & $1.78 \pm 0.72(0.31)$ & $1.8 .7 \pm 6.0(0.32)$ & $31.3 \pm 10.7(0.30)$ & $34.3 \pm 11.5(0.32)$ \\
$37^{\circ} \mathrm{C} / 25^{\circ} \mathrm{C}$ & & $1.64 \pm 0.29$ & $1.73 \pm 0.45$ & $1.70 \pm 0.73$ & $1.75 \pm 1.04$ \\
\hline
\end{tabular}


Scrum choline esterase levels with various substrates in normal subjects and patients with various hepatic diseases

In experiment 1 , the enzyme activity with 0 toluoylcholine as substrate was assayed at $37^{\circ} \mathrm{C}$ and compared with the measured activities against acetyl-, butyryl-, and propionyl-thiocholine. No significant difference in the average values with all these substrates was observed between normal individuals and patients with acute or chronic hepatitis $(p>0.1)$, though enzyme activity tended to decrease in patients with chronic active hepatitis (tab. 2). However, in hepatic cirrhosis a marked decrease in enzyme activity with all these substrates was observed $(p<0.01)$. A significant difference was observed between acute or chronic hepatitis and hepatic cirrhosis $(\mathrm{p}<0.01$ in each choline esterase catalytic concentration). In primary and secondary hepatic carcinoma these enzyme activities were also decreased, being at levels similar to those of hepatic cirrhosis (tab. 2). In benign cholestatic disorders, these choline esterase activities were within normal limits (tab. 2). The decreased rates of the enzyme activity with these various substrates in hepatic disorders were not significantly different ( $p>0.1$, tab. 2).
In experiment 2 , the serum enzyme activity against succinylcholine in hepatic disease determined at $37^{\circ} \mathrm{C}$ was compared with that against acetyl-, butyryl-, and propionyl-thiocholine. The serum enzyme activity against succinylcholine was markedly decreased in the serum of patients with hepatic cirrhosis ( $p<$ 0.01, tab. 3 ). The decreased rate of the enzyme activity against succinylcholine in hepatic cirrhosis was not significantly different from that for other substrates ( $p>0.1$, tab. 3).

A good correlation was observed between the enzyme activities for these different substrates in various sera (fig. 4).

Frequency of abnormalities of serum choline esterase activity in chronic liver disease

In various hepatic disorders, particularly in hepatic cirrhosis and carcinoma, lower values of choline esterase were observed (tab. 2 and 3). Therefore, an attempt was made to determine the discriminating level for the differentiation of chronic active hepatic disease from other hepatic disease.

Tab. 2. Serum choline esterase activity $\left(37^{\circ} \mathrm{C}\right)$ with various substrates in normal subjects and in patients with hepatic disease.

\begin{tabular}{|c|c|c|c|c|c|}
\hline & \multirow[b]{2}{*}{$\begin{array}{l}\text { No. of } \\
\text { cases }\end{array}$} & \multicolumn{4}{|c|}{$\begin{array}{l}\text { Enzyme catalytic activity concentration, substrate hydrolysed } \\
{[\mu \mathrm{mol} / \mathrm{s} \cdot 1](\overline{\mathrm{x}} \pm \mathrm{SD})}\end{array}$} \\
\hline & & $o$-Toluoylcholine & Acetylthiocholine & Butyrylthiocholine & Propionylthiocholine \\
\hline Normal subjects & 61 & $8.2 \pm 1.3$ & $67.7 \pm 10.1$ & $89.2 \pm 18.8$ & $119.0 \pm 21.0$ \\
\hline Acute hepatitis & 23 & $7.5 \pm 1.8$ & $63.0 \pm 14.0$ & $82.0 \pm 18.7$ & $110.0 \pm 24.5$ \\
\hline Chronic hepatitis & 50 & $7.0 \pm 2.3$ & $59.2 \pm 18.7$ & $74.8 \pm 24.0$ & $103.2 \pm 33.7$ \\
\hline persistent & 27 & $7.8 \pm 1.7$ & $65.0 \pm 13.3$ & $83.3 \pm 16.3$ & $113.7 \pm 23.8$ \\
\hline active & 23 & $6.0 \pm 2.5$ & $50.3 \pm 19.3$ & $62.8 \pm 22.3$ & $87.0 \pm 33.2$ \\
\hline Hepatic cirrhosis & 32 & $3.2 \pm 1.2$ & $28.8 \pm 9.7$ & $36.3 \pm 13.0$ & $47.0 \pm 17.5$ \\
\hline Bile duct obstruction, benign & 9 & $7.2 \pm 1.8$ & $61.7 \pm 17.5$ & $89.0 \pm 25.2$ & $110.3 \pm 30.5$ \\
\hline Hepatic carcinoma with cirrhosis & 6 & $2.7 \pm 1.2$ & $25.0 \pm 8.5$ & $29.0 \pm 10.8$ & $39.7 \pm 15.3$ \\
\hline Hepatoma, primary & 20 & $3.3 \pm 1.7$ & $30.3 \pm 14.0$ & $38.7 \pm 17.3$ & $50.8 \pm 23.2$ \\
\hline Metastatic cancer & 9 & $3.5 \pm 1.3$ & $29.5 \pm 11.2$ & $39.3 \pm 12.8$ & $51.2 \pm 18.0$ \\
\hline
\end{tabular}

Tab. 3. Serum choline esterase activity $\left(37^{\circ} \mathrm{C}\right)$ with various substrates in normal subjects and in patients with hepatic disease.

\begin{tabular}{lllllll}
\hline & \multicolumn{4}{l}{$\begin{array}{l}\text { Enzyme catalytic activity concentration, substrate hydrolysed } \\
{[\mu \mathrm{mol} / \mathrm{s} \cdot 1](\overline{\mathbf{x}} \pm \mathrm{SD})}\end{array}$} \\
& No. of cases & Succinylcholine & Acethylthiocholine & Butyrylthiocholine & Propionylthiocholine \\
\hline Normal subjects & 16 & $1.2 \pm 0.2$ & $59.0 \pm 11.3$ & $100.5 \pm 23.7$ & $107.7 \pm 25.8$ \\
Acute hepatitis & 7 & $1.1 \pm 0.1$ & $51.3 \pm 9.3$ & $90.0 \pm 16.3$ & $101.7 \pm 17.2$ \\
Chronic hepatitis & 8 & $0.9 \pm 0.3$ & $35.7 \pm 15.5$ & $64.0 \pm 25.7$ & $76.3 \pm 31.2$ \\
Hepatic cirrhosis & 15 & $0.3 \pm 0.01$ & $18.5 \pm 0.5$ & $27.2 \pm 9.7$ & $31.7 \pm 10.2$ \\
\hline
\end{tabular}




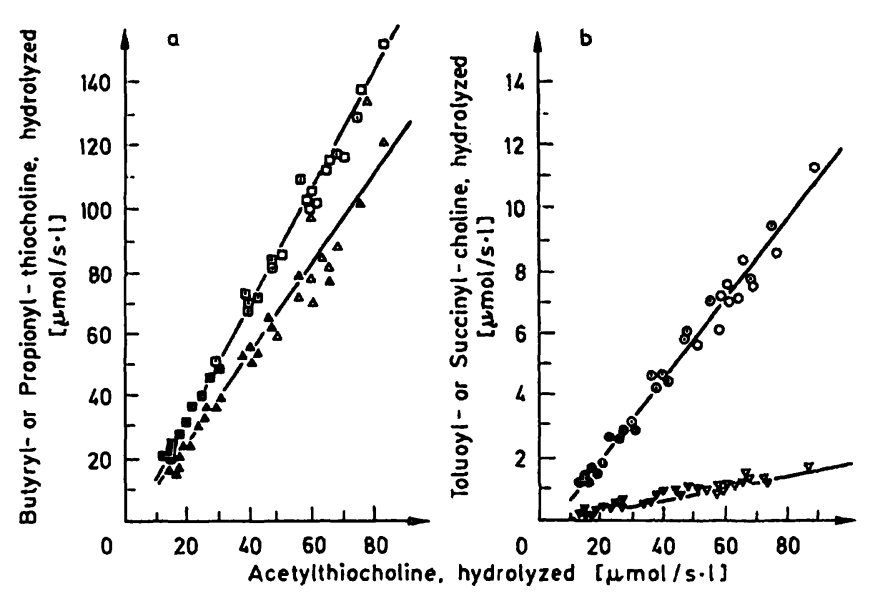

Fig. 4. Correlation between the serum activities of choline esterase, measured with acetylthiocholine as substrate and with various other substrates.

a) Substrate: butyrylthiocholine (normal $\Delta$, hepatitis $\Delta$, hepatic cirrhosis $\Delta$ ) $n=30, r=0.96(p<0.001), y=1.46 x$ $-5.25$

Substrate: propionylthiocholine (normal $\square$, hepatitis $\square$, hepatic cirrhosis $\square$ ) $\mathrm{n}=30, \mathrm{r}=0.99(\mathrm{p}<0.001), \mathrm{y}=1.89 \mathrm{x}$ -6.73 .

b) Substrate: $o$-toluoylcholine (normal $\circ$, hepatitis $\odot$, hepatic cirrhosis o) $\mathrm{n}=30, \mathrm{r}=0.98(\mathrm{p}<0.001), \mathrm{y}=$ $0.134 x-0.68$.

Substrate: succinylcholine (normal $\nabla$, hepatitis $\nabla$, hepatic cirrhosis $\nabla$ )

$\mathrm{n}=30, \mathrm{r}=0.94(\mathrm{p}<0.001), \mathrm{y}=$ $0.019 x-0.035$.
An enzyme activity against acetylthiocholine below $50 \%$ of the average level of normal subjects was seen in $1(4 \%)$ of 23 cases of acute hepatitis, $6(12 \%)$ of 50 patients with chronic hepatitis and $25(78 \%)$ of 32 patients with hepatic cirrhosis (tab. 4). With butyrylthiocholine, a lower enzyme activity than $50 \%$ of the average normal value was observed in $2(8 \%)$ of 23 cases of acute hepatitis, $7(14 \%)$ of 50 chronic hepatitis patients and $25(78 \%)$ of 32 patients with hepatic cirrhosis (Tab. 4). With propionyl-thiocholine, an activity below $50 \%$ of the average normal level was found in $1(4 \%)$ of 23 acute hepatitis, 6 $(12 \%)$ of 50 chronic hepatitis and $25(78 \%)$ of 32 hepatic cirrhosis patients (Tab. 4). With o-toluoylcholine an enzyme level lower than $50 \%$ of the average normal value was found in $2(9 \%)$ of 23 acute hepatitis, $6(12 \%)$ of 50 chronic hepatitis, and $27(84 \%)$ of 32 hepatic cirrhosis patients (tab. 4).

In these 32 hepatic cirrhosis patients, 12 (37\%) had developed the disorder about a year previously, and $5(16 \%), 3(9 \%), 5(16 \%)$ and $6(19 \%)$ about $2,3,4$ and 5 years previously, respectively, and one $(3 \%)$ had had the disorder for over 10 years. Of these, 18 (56\%) were postnecrotic cirrhosis, $13(41 \%)$ alcoholic, and one (3\%) biliary. In 7 cirrhosis patients with relatively higher choline esterase activity, 4 showed the onset of disease 1-2 years ago, and the other $3-5$ years ago.

Tab. 4. Frequency of abnormalities of serum choline esterase activity $\left(37^{\circ} \mathrm{C}\right)$ in patients with various hepatic disease.

\begin{tabular}{|c|c|c|c|c|c|c|c|c|c|}
\hline & \multirow{3}{*}{$\begin{array}{l}\text { No. of } \\
\text { cases }\end{array}$} & \multicolumn{8}{|c|}{ Number of patients with choline esterase catalytic concentration $[\mu \mathrm{mol} / \mathrm{s} \cdot 1]$} \\
\hline & & \multicolumn{2}{|c|}{ o-Toluoylcholine } & \multicolumn{2}{|c|}{ Acetylthiocholine } & \multicolumn{2}{|c|}{ Butyrylthiocholine } & \multicolumn{2}{|c|}{ Propionylthiocholine } \\
\hline & & A & B & A & B & A & B & A & B \\
\hline & & $<4.1$ & $<4.9$ & $<33.9$ & $<40.6$ & $<44.6$ & $<53.5$ & $<59.5$ & $<71.3$ \\
\hline Acute hepatitis & 23 & $\begin{array}{l}2 \\
(0.09)\end{array}$ & $\begin{array}{l}4 \\
(0.17)\end{array}$ & $\begin{array}{c}1 \\
(0.04)\end{array}$ & $\begin{array}{l}2 \\
(0.09)\end{array}$ & $\begin{array}{l}2 \\
(0.09)\end{array}$ & $\begin{array}{l}4 \\
(0.17)\end{array}$ & $\begin{array}{c}1 \\
(0.04)\end{array}$ & $\begin{array}{l}4 \\
(0.17)\end{array}$ \\
\hline Chronic hepatitis & 50 & $\begin{array}{l}6 \\
(0.12)\end{array}$ & $\begin{array}{l}13 \\
(0.26)\end{array}$ & $\begin{array}{l}6 \\
(0.12)\end{array}$ & $\begin{array}{l}12 \\
(0.24)\end{array}$ & $\begin{array}{l}7 \\
(0.14)\end{array}$ & $\begin{array}{l}11 \\
(0.22)\end{array}$ & $\begin{array}{l}6 \\
(0.12)\end{array}$ & $\begin{array}{l}12 \\
(0.24)\end{array}$ \\
\hline Hepatic cirrhosis & 32 & $\begin{array}{l}27 \\
(0.84)\end{array}$ & $\begin{array}{l}29 \\
\cdot(0.91)\end{array}$ & $\begin{array}{l}25 \\
(0.78)\end{array}$ & $\begin{array}{l}29 \\
(0.91)\end{array}$ & $\begin{array}{l}25 \\
(0.78)\end{array}$ & $\begin{array}{l}30 \\
(0.94)\end{array}$ & $\begin{array}{l}25 \\
(0.78)\end{array}$ & $\begin{array}{l}29 \\
(0.91)\end{array}$ \\
\hline $\begin{array}{l}\text { Bile duct obstruction, } \\
\text { benign }\end{array}$ & 9 & $\begin{array}{c}0 \\
(0)\end{array}$ & $\begin{array}{c}0 \\
(0)\end{array}$ & $\begin{array}{c}0 \\
(0)\end{array}$ & $\begin{array}{c}0 \\
(0)\end{array}$ & $\begin{array}{c}0 \\
(0)\end{array}$ & $\begin{array}{c}0 \\
(0)\end{array}$ & $\begin{array}{c}0 \\
(0)\end{array}$ & $\begin{array}{c}0 \\
(0)\end{array}$ \\
\hline $\begin{array}{l}\text { Hepatic carcinoma } \\
\text { with cirrhosis }\end{array}$ & 6 & $\begin{array}{l}6 \\
(1.00)\end{array}$ & $\begin{array}{l}6 \\
(1.00)\end{array}$ & $\begin{array}{l}4 \\
(0.67)\end{array}$ & $\begin{array}{l}6 \\
(1.00)\end{array}$ & $\begin{array}{l}5 \\
(0.83)\end{array}$ & $\begin{array}{l}6 \\
(1.00)\end{array}$ & $\begin{array}{c}5 \\
(0.83)\end{array}$ & $\begin{array}{c}6 \\
(1.00)\end{array}$ \\
\hline Hepatoma, primary & 20 & $\begin{array}{l}14 \\
(0.70)\end{array}$ & $\begin{array}{l}16 \\
(0.80)\end{array}$ & $\begin{array}{l}14 \\
(0.70)\end{array}$ & $\begin{array}{l}16 \\
(0.80)\end{array}$ & $\begin{array}{l}14 \\
(0.70)\end{array}$ & $\begin{array}{l}16 \\
(0.80)\end{array}$ & $\begin{array}{l}14 \\
(0.70)\end{array}$ & $\begin{array}{l}16 \\
(0.80)\end{array}$ \\
\hline $\begin{array}{l}\text { Metastatic hepatic } \\
\text { carcinoma }\end{array}$ & 9 & $\begin{array}{l}7 \\
(0.78)\end{array}$ & $\begin{array}{l}8 \\
(0.89)\end{array}$ & $\begin{array}{l}5 \\
(0.56)\end{array}$ & $\begin{array}{c}8 \\
(0.89)\end{array}$ & $\begin{array}{l}6 \\
(0.67)\end{array}$ & $\begin{array}{c}7 \\
(0.78)\end{array}$ & $\begin{array}{c}5 \\
(0.56)\end{array}$ & $\begin{array}{c}8 \\
(0.89)\end{array}$ \\
\hline
\end{tabular}

$A$ and $B$ indicate the 0.5 and 0.6 activity fractions referred to the average normal values, respectively.

Figures in parentheses are the number fractions referred to the total patient numbers (No. of cuses) in each disease group. 
Clinical course of chronic hepatitis with abnormally low choline esterase activity and hepatic cirrhosis with relatively higher choline esterase activity

In 8 of 50 patients with chronic hepatitis studied over a period from January to December 1979 (tab. 2), a lower value of choline esterase below $50 \%$ of the average normal level with acetyl-, butyryl-, or propionyl-thiocholine was observed. A follow up study of these patients showed that 6 of these 8 patients had developed hepatic cirrhosis by 1982 , resulting in a poor prognosis.

In 7 out of 32 patients with hepatic cirrhosis studied over the period from January to December 1979 (tab. 2 ), a higher choline esterase activity than $50 \%$ of the average normal level with acetyl-, butyryl-, or propionyl-thiocholine was observed. Of these, 3 patients had hepatic cirrhosis for a year, and 1, 2, and 1 patients for 2,3 , and 5 years, respectively. Postnecrotic cirrhosis was seen in 5 patients and alcoholic in 2 . A follow up study indicated that 5 of these 7 patients showed a progressive decrease in activity and died by 1983 . Of these 5 deaths, 4 were due to bleeding from oesophageal varices and 1 due to bacterial infection.

\section{Discussion}

For the determination of choline esterase activity, various methods have developed with various choline esters. The optimal $\mathrm{pH}$ for the assay varies with the type and ionic strength of the buffer, with the substrate concentration, and also with the enzyme variants $(2,25)$. The serum pseudocholine esterase had an optimal $\mathrm{pH}$ of $8.5-9.0$ with substrates used under the conditions of the present study, agreeing with the results of previous workers $(2,25)$. However, a $\mathrm{pH}$ of 7.5, as used in the present work, is generally preferred (2), because there is an apparent increase in spontaneous hydrolysis of substrate with increasing $\mathrm{pH}(2)$.

Previous studies recommend an assay temperature of $37^{\circ} \mathrm{C}$, since a better separation of phenotypes occurs at $37^{\circ} \mathrm{C}$ than at $25^{\circ} \mathrm{C}(26-28)$. Similarly, in the present study, $37^{\circ} \mathrm{C}$ was superior to $25^{\circ} \mathrm{C}$ for assessing hepatic function when the assay was conducted with a short incubation time, e. g. $5 \mathrm{~min}$, because these conditions gave a better differentiation of the decreased enzyme activity in hepatic cirrhosis. However, at $25^{\circ} \mathrm{C}$, the decreased enzyme activity in hepatic cirrhosis was well differentiated when longer periods of incubation, such as $10 \mathrm{~min}$, were used. Furthermore, in this study the decreased rates of serum choline esterase activity in hepatic cirrhosis measured at 25,30 , and $37^{\circ} \mathrm{C}$ were not significantly different. Therefore, if optimal assay conditions were used, no significant difference was observed in the results obtained either at 25,30 , or $37^{\circ} \mathrm{C}$ with respect to the assay of decreased serum choline esterase activity for the evaluation of liver disease.

Since butyrylthiocholine is the least labile of the thiocholinesters and because it is relatively specific for human serum pseudocholine esterase (2), it has been recommended and used as the substrate of choice for routine purposes $(2,29-31)$. Furthermore, $o$-toluoylcholine has been reported to be as stable as butyrylthiocholine and more specific for human serum pseudocholine esterase than butyrylthiocholine (15). Although propionylthiocholine is recommended as a better substrate than butyrylthiocholine for the differentiation of the phenotypes of pseudocholine esterase $(10-12)$, succinylcholine may be the most suitable substrate for direct detection of succinylcholine sensitivity (6).

With respect to the specificity of substrates for measuring serum pseudocholine esterase for the as= sessment of hepatic function, Prellwitz et al. (14) have reported that in hepatic cirrhosis and also in chronic hepatitis the activities of serum choline esterase determined at $25^{\circ} \mathrm{C}$ with acetyl-, butyryl-, or propionylthiocholine all showed similar decreases, and revealed no significant differences in the specificities of substrates. Likewise, in the present study the decreased choline esterase activity in hepatic cirrhosis was observed with each of these substrates. In the present study, each of these substrates revealed the same decrease of enzyme activity when the assay was conducted at $37^{\circ} \mathrm{C}$, thus confirming the finding of Prellwitz et al at $25^{\circ} \mathrm{C}$. Furthermore, the serum choline esterase activity determined with o-toluoylcholine and succinylcholine decreased at a similar rate compared with the enzyme activity determined with acetyl-, butyryl-, and propionyl-thiocholine. Thus, the present study indicates no significant difference in specificity of various substrates with respect to the evaluation of hepatic function.

Under the conditions of the present study with acetyl-, butyryl-, and propionyl-thiocholine, and o-toluoylcholine, in $78-84 \%$ of cases with hepatic cirrhosis the enzyme activity was less than $50 \%$ of average levels of normal individuals, but in acute and chronic hepatitis only $4-9$ and $12-14 \%$ of patients showed the lower values, respectively. In $17(53 \%)$ 
out of 32 hepatic cirrhosis patients, the onset of disease was within the previous 2 years. Of these 17 patients, $13(76 \%)$ had the lower values. These findings indicate the usefulness of the serum choline esterase assay with any of these substrates for assessing chronic hepatic disease. Furthermore, the present study suggests that succinylcholine is also useful for evaluating hepatic function.

\section{References}

1. Pilz, W. (1974) Methods of Enzymatic Analysis (Bergmeyer, H. U. ed.) Verlag Chemie - Academic Press, pp. 831 - 855.

2. Silk, E., King, J. \& Whittaker, M. (1979) Ann. Clin. Chem. 16. $57-75$.

3. Brown, S. S., Kalow, W., Pilz, W., Whittaker, M. \& Woronick, C. L. (1981) Adv. Clin. Chem. 22, 1-123.

4. Hunt, A. H. \& Lehmann, H. (1960) Gut 1, 303-311.

5. Evans, D. B. \& Lehmann, H. (1971) Lancet $I, 1040-1044$.

6. Abernethy, M. H., George, P. M. \& Melton, V. E. (1984) Clin. Chem. 30, 192-195.

7. Fishtal, A., Evans, R. T. \& Chapman, C. N. (1972), J. Clin. Pathol. 25, 422-426.

8. Agarwal, D. P., Schwenkenbecher, S., Strivastava, L. M. \& Goedde, H. W. (1975) J. Clin. Chem. Clin. Biochem. 13, $133-135$.

9. Agarwal, D. P. \& Goedde, H. W. (1976) J. Chromatogr. $121,170-172$.

10. Dietz, A. A., Rubinstein, H. M., Lubrano, T. \& Hodges, L. K. (1972) Am. J. Human Genet. 24, 58-64.

11. Dietz, A. A., Rubenstein, H. M. \& Lubrano, T. (1973) Clin. Chem. 19, 1309-1313.

12. Evans, R. T. \& Wroe, J. (1978) Clin. Chem. 24, 1762-1766.

13. Brown, S. S. \& Price, E. M. (1975) Clin. Chem. 21, $1041-1042$.

14. Prellwitz, V. W., Kapp, S. \& Muller, D. (1976) J. Clin. Chem. Clin. Biochem. 14, 93-97.

15. Okabe, H., Kita, M., Netsu-Nakayama, K., Yamamoto, T., Watanabe, K., Shimizu, Y. \& Noma, A. (1980) Clin. Chim. Acta 103, 349-355.

16. Uete, T., Miyamoto, Y., Ohnishi, M. \& Shimano, N. (1972) Clin. Chem. 18, 454-458.
In addition, the present findings support the contention that sequential measurement of the serum choline esterase activity is valuable for monitoring the course of hepatic disorders $(3,4,32)$. The results of the present study, together with several published comments $(3,4,32)$, suggest that reduction of choline esterase activity to about one quarter of a given patient's normal activity, usually heralds that person's death.

17. Geall, M. G., Shoenfield, L. J. \& Summerskill, W. H. J. (1968) Gastroenterology 55, 724-729.

18. Soloway, R. D., Summerskill, V. H. J., Baggestoss, A. H., Geall, M. G., Gitnick, G. L., Elveback, L. R. \& Shoenfield, L. J. (1972) Gastroentcrology 63, 820-833.

19. Summerskill, W. H. J. (1975), Am. J. Dig. Dis. 20, 1087-1090.

20. Czaja, A.J., Wolr, A. M. \& Baggenstoss, A. H. (1980) Mayo Clin. Proc. 55, 360-364.

21. Czaja, A. J. (1981) Mayo Clin. Proc. 56, 311-323.

22. De Groote, J., Desmet, V. J., Gedigk, P., Korb, G., Popper, H., Poulsen, H., Scheuer, P. J., Schmid, M., Thaler, H., Uehlinger, E. \& Wepler, M. (1968) Lancet II, 626-628.

23. Scheuer, P. J. (1970) Gut 11, 275-278.

24. Soloway, R. D., Baggenstoss, A. H., Schoenfield, L. J. \& Summerskill, W. H. J. (1971) Am. J. Dig. Dis. 16, 1082-1086.

25. Kalow, W. (1964) Canad. J. Physiol. Pharmacol. 42, $161-168$.

26. King. J., McQueen, M. J. \& Morgan, H. G. (1971) Br. J. Anaesthesia 43, 669-672.

27. King, J. \& Ritchie, G. (1973) Proceedings of the 5th International Symposium on Clinical Enzymology 2, 347-358.

28. King, J. \& Griffin, D. (1974) Br. J. Anaesthesia 46, 908-911.

29. Das, P. K. \& Liddell, J. (1970) J. Med. Genet. 7, 351 - 355.

30. Garry, P. J., Owen, G. H. \& Lubin, A. H. (1972) Clin. Chem. 18, 105-109.

31. Karahasanoglu, A. M. \& Ozand, P. T. (1967) J. Lab. Clin. Gastroenterology 33, 50-57.

Dr. Tetsuo Uetc

Department of Clinical Investigation

Kitano Hospital,

Tazuke Kofukai Mcdical Research Institute 13-3 Kamiyamachyo, Kita-ku, Osaka City Japan 530 
